OPEN ACCESS

Edited by:

Roland Wohlgemuth,

Sigma-Aldrich, Switzerland

Reviewed by:

Henrik R. Nilsson,

University of Gothenburg, Sweden

llana Kolodkin-Gal,

Weizmann Institute of Science, Israel

Antje Labes,

Fachhochschule Flensburg, Germany

*Correspondence:

Carla C. C. R. de Carvalho

ccarvalho@tecnico.ulisboa.pt

Specialty section:

This article was submitted to

Marine Biotechnology,

a section of the journal

Frontiers in Marine Science

Received: 25 November 2017

Accepted: 26 March 2018

Published: 11 April 2018

Citation:

de Carvalho CCCR (2018) Marine

Biofilms: A Successful Microbial

Strategy With Economic Implications.

Front. Mar. Sci. 5:126.

doi: 10.3389/fmars.2018.00126

\section{Marine Biofilms: A Successful Microbial Strategy With Economic Implications}

\author{
Carla C. C. R. de Carvalho*
}

Department of Bioengineering, Institute for Bioengineering and Biosciences, Instituto Superior Técnico, Universidade de Lisboa, Lisbon, Portugal

Bacteria and other microorganisms have evolved an ingenious form of life, where they cooperate and improve their chances of survival when subjected to environmental stress, called biofilms. In these communities of adhered cells, bacteria are protected by a matrix of extracellular polymeric substances that provide protection against e.g., temperature and $\mathrm{pH}$ fluctuations, UV exposure, changes in salinity, depletion of nutrients, antimicrobial compounds, and predation. Their success in marine environments and the number of bacterial cells in the sea, allow them to colonize nearly all man-made surfaces in contact with seawater. The costs to maritime transport, aquaculture, oil and gas industries, desalination plants and other industries are significant which has led to the development of various strategies to prevent biofilm formation and cleaning of infected surfaces. In this review, the benefits for bacterial cells to live in biofilms and the consequences to human activities are discussed.

\section{Keywords: bacteria, fouling, surface, adhesion, mats}

\section{INTRODUCTION}

Bacteria play important roles in marine environments, including driving biogeochemical cycles (Paerl and Pinckney, 1996; Hawley et al., 2017) and supplying materials and energy to higher trophic levels (Azam et al., 1983; de Carvalho and Caramujo, 2012). The phenotypic plasticity of bacteria is responsible for their success and ubiquity (Brown and Williams, 1985; López-Maury et al., 2008). Although genotypic evolution may contribute a significant selective advantage to environmental stimuli, phenotypic plasticity allows bacteria to grow and thrive under fluctuating, challenging conditions such as those found in the marine environment (Bijlsma and Loeschcke, 2005; Brooks et al., 2011).

One of the most successful phenotypes derives from the adhesion of bacterial cells to surfaces. After adhesion, bacterial cells produce an extracellular polymeric substance (EPS) matrix, establishing the formation of a biofilm (Costerton et al., 1978, 1995; Flemming and Wingender, 2001, 2010; Steinberg and Kolodkin-Gal, 2015; Flemming, 2016). This strategy has protected cells for billions of years from environmental conditions, as fossils demonstrate (Rasmussen, 2000; Westall et al., 2001), and has allowed them to colonize nearly all habitats on Earth. An attached cell may benefit from features of the solid-liquid interface, in particular, the hydrodynamic conditions and nutrients adsorbed at the surface (Fletcher, 1991).

The observation that the number of bacteria in stored raw seawater in the laboratory increased greatly and faster in small samples than in larger volumes led ZoBell and Anderson in 1936 to test if the number of cells was related to the volume of the flasks used for cell growth (ZoBell and Anderson, 1936). They used Pyrex bottles with similar geometries and containing 10-10,000 mL 
of raw sea water and assessed the effect of liquid volume, oxygen and surface area per unit volume on the number of bacteria. The authors observed a dramatically higher number of bacteria on surfaces when compared to sea water, and acknowledge the importance of solid surfaces to cell growth and activity. A few years later, ZoBell showed that many bacteria found in seawater are sessile and produce a "mucilaginous holdfast" (ZoBell, 1943). However, it was only in 1978 that Costerton and co-workers proposed a "biofilm theory" (Costerton et al., 1978). Since then, both mechanisms involved in biofilm formation and methods to demote and prevent biofilms have been widely studied (see e.g., Donlan, 2001; de Carvalho and de Fonseca, 2007; Landini, 2009; de Carvalho, 2012b; de la Fuente-Núñez et al., 2012; Gu et al., 2013; Rabin et al., 2015).

Biofilms have been referred to by several terms, including periphyton and mycrophytobenthos. The term periphyton was proposed by Behnin in 1924 and was used to describe organisms growing attached to artificial surfaces in water (Cooke, 1956). Periphyton is defined as a complex community mainly composed of photoautotrophic algae, heterotrophic bacteria, fungi, protozoans, metazoans and viruses, and inorganic and organic detritus, which is attached to inorganic or organic benthic substrates. This term is frequently used in freshwater ecology and aquaculture pond systems. On the other hand, microphytobenthos is used in marine ecosystems to describe the photosynthetic microorganisms, such as cyanobacteria and eukaryotic algae, that adhere to illuminated sediments (MacIntyre et al., 1996). Nevertheless, various definitions of these terms, such as the definition of periphyton communities as complex phototrophic, multispecies biofilms attached to surfaces in aquatic environments, including marine habitats (Sanli et al., 2015), can be found in the literature. For this reason, the broader term "biofilm" will be used throughout this manuscript.

Biofilms usually start with the adhesion of bacterial cells which modify the surface physicochemical properties, thus influencing the adhesion of successive colonizers such as algae, cyanobacteria, and protists (Wetzel, 2001; Dang and Lovell, 2016). The adsorption of macromolecules to a surface starts within seconds after immersion, bacterial colonization begins after ca. an hour, and colonization by unicellular eukaryotes (e.g., diatoms, yeasts, and protozoa) usually starts several days after immersion (Wahl, 1989). Colonization by multicellular eukaryotes follows. Bacteria and diatoms have been found to dominate marine biofilms but the ratio bacteria:diatoms:flagellates observed in biofilms in the White Sea was 640:4:1 (Railkin, 2003). Bacteria of the order Rhodobacterales, in particular of the Roseobacter clade, were found to be primary colonizers on freshly submerged surfaces probably due to a fast response to the presence of nutrients in the conditioning film formed (Dang et al., 2008). In fact, bacteria have been found to be the most important microbes on marine surfaces and, by being early colonizers, these cells may determine the structure and function of the mature biofilm (Dang et al., 2008; Dang and Lovell, 2016).

The challenging conditions to microbes found in marine environments favor their aggregation and adhesion to both natural and man-made surfaces. Numerous compounds accumulate on submerged surfaces and biogenic particles consist mainly of carbon rich skeletal remains of e.g., planktonic organisms (Costerton et al., 1995; Dang and Lovell, 2016; Furey et al., 2017). These compounds may be used by bacteria as e.g., carbon and energy sources, micronutrients, and electron donors/acceptors in metabolic reactions. The most important advantage for bacteria in marine biofilms is, probably, the access to these resources (Costerton et al., 1995; Dang and Lovell, 2016). However, biofilms also protect individual cells against environmental stress, including desiccation, temperature and $\mathrm{pH}$ changes, competition and predation, UV exposure, and depleted nutrient conditions (Figure 1).

Marine biofilms easily colonize man-made surfaces, accelerating corrosion (Little et al., 2008), biofouling (Cao et al., 2011), and may even influence the buoyance of polyethylene plastic (Lobelle and Cunliffe, 2011). Together with diatoms and other microorganisms, bacteria are responsible for microfouling, allowing the adhesion of larger organisms such as algae, mussels and barnacles which cause macrofouling (Cao et al., 2011). The costs to several industries are substantial (Table 1). The environmental impact of biofouling is also significant. Besides indirect repercussion from increased energy consumption necessary to e.g., overcome increased frictional drag and heat and mass transfer limitations (Schultz et al., 2011), biofouling organisms reduce water flow and increase biodeposition beneath aquaculture farms (Fitridge et al., 2012), and may be fish pathogens (Floerl et al., 2016). The strategies to prevent cell adhesion and biofilm formation usually involve the use of an antimicrobial/antiadhesion coating, release of a toxic agent such as metal ions at the surface or smart surfaces (de Carvalho and de Fonseca, 2007; de Carvalho, 2012b). The environmental fate and effects of these biocides should also be considered during biofouling management and control.

\section{MARINE BIOFILMS PROTECT BACTERIA FROM HARSH ENVIRONMENTAL CONDITIONS}

The heterogeneous character of marine environments constitutes a challenge for bacterial survival. A non-motile bacterium with an average cell diameter of $0.4-2 \mu \mathrm{m}$ may uptake nutrients from the diffusion boundary layer which typically spans a few cell diameters, with Brownian diffusion allowing the cells to explore ca. $45 \mathrm{pL}$ of seawater in $10 \mathrm{~min}$ (Stocker, 2012). A swimming bacterium may experience $0.5 \mu \mathrm{L}$ of new water every $10 \mathrm{~min}$, while a chemotactic velocity of $10 \mu \mathrm{m} / \mathrm{s}$ may allow the cell to travel $6 \mathrm{~mm}$ in $10 \mathrm{~min}$. As noted by Stocker, even a $\mathrm{mL}$ of seawater may be quite heterogeneous because (i) the substrates necessary are heterogeneous at microbial scale (e.g., 10-1,000 $\mu \mathrm{m}$ oil droplets and 50-5,000 $\mu \mathrm{m}$ gas bubbles), (ii) turbulence creates gradients of e.g., dissolved organic matter at the microscale, and (iii) chemical and physical gradients, including viscosity, fluid velocity and salinity gradients, occur due to polymer webs, turbulent shear, and release of interstitial fluid carried by porous materials (Stocker, 2012). One must bear in mind that small organisms are passively transported by sea currents and their chemotaxis toward a surface can only occur if the 


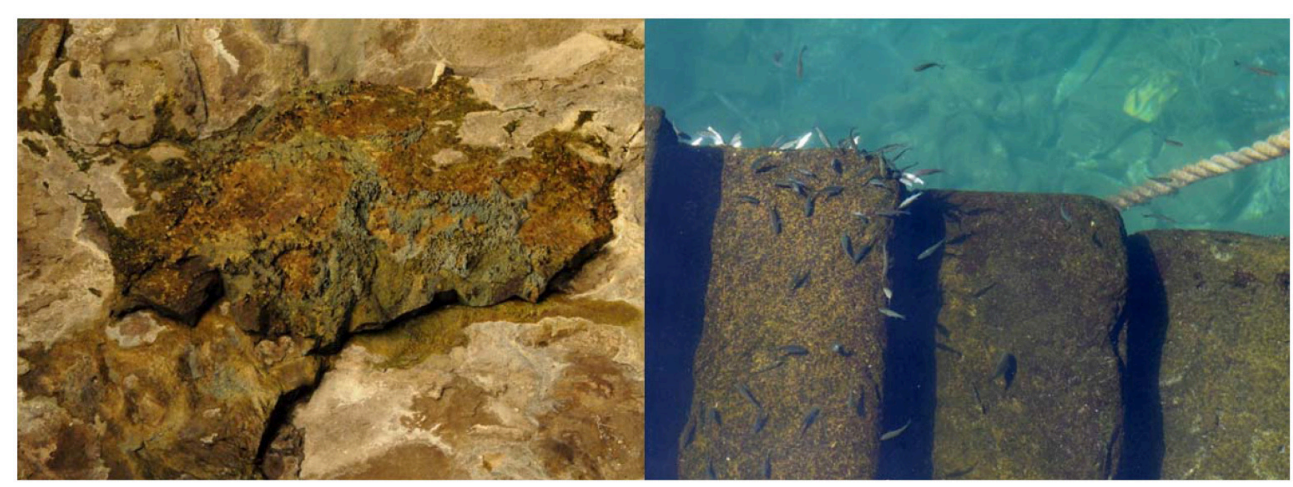

FIGURE 1 | Bacterial biofilms provide protection to indicidual cells against e.g., desiccation in intertidal zones (A) and predation (B).

TABLE 1 | Estimated costs due to biofilm formation in industrial activities.

\begin{tabular}{|c|c|c|c|}
\hline Industry & Problem & Estimated cost & References \\
\hline \multirow[t]{2}{*}{ Aquaculture } & Fouling of both stock and infrastructures & 1.5-3 billion US dollars per year & Fitridge et al., 2012 \\
\hline & Biofouling on fish cages and shellfish sites & $\begin{array}{l}5-10 \% \text { of the industry value in Europe (ca. } 260 \\
\text { million euros per year) }\end{array}$ & Lane and Willemsen, 2004 \\
\hline Heat exchange & $\begin{array}{l}\text { Decreased heat transfer and induced } \\
\text { corrosion }\end{array}$ & ca. $7.5 \%$ of maintenance costs of a process plant & Ibrahim, 2012 \\
\hline Oil and gas industry & Microbial influenced corrosion & $20-30 \%$ of corrosion-related costs & Skovhus et al., 2017 \\
\hline \multirow[t]{2}{*}{ Maritime transport } & Increased drag & $35-50 \%$ increased fuel consumption & Schultz et al., 2011 \\
\hline & $\begin{array}{l}\text { Fouling of ballast water with } \\
\text { non-indigenous species }\end{array}$ & $1.6-4 \%$ of annual operational cost for a ship & Fernandes et al., 2016 \\
\hline Water desalination & Biofouling of reverse osmosis membranes & $\begin{array}{l}5-20 \% \text { of operational costs for cleaning; cost of } \\
\text { biofouling ca. } 30 \% \text { of total operating costs }\end{array}$ & $\begin{array}{l}\text { Flemming, 1997; Maddah and Chogle, } \\
2017\end{array}$ \\
\hline
\end{tabular}

microorganism is close to the surface (Railkin, 2003). However, the low probability of the encounter between a given cell and a surface is counteracted by the number of microorganisms in natural seawater, estimated at $5 \times 10^{5}$ cells $/ \mathrm{mL}$ in the continental shelf and upper $200 \mathrm{~m}$ of open ocean water (Whitman et al., 1998).

Bacterial cells can also present multicellular structures, such as chains that result from incomplete separation of daughter cells after cell division, cell aggregates, and clusters. The benefits for cells in large size filaments and clusters include: reduced susceptibility to predators; and improved nutrient acquisition since enzymes necessary to metabolize complex substrates may be used to feed neighboring cells (Claessen et al., 2014). To survive predation, cells in biofilms may produce antipredator chemicals such as violacein which is a potent antiprotozoal compound (Matz et al., 2008). Furthermore, marine bacteria may present a diverse range of phenotypes and cell-cell interactions. For example, strain SW5 isolated from surfboard wax formed a compact, multilayered single- and double-cell biofilm on hydrophobic surfaces (Dalton et al., 1996). However, this strain developed long, multicellular chains on hydrophilic surfaces.

Access to nutrients may vary substantially in the marine environment: open ocean water is usually nutrient depleted whereas coastal and estuarine regions may be nutrient rich (Giraud et al., 2008). Between marine bacteria two major groups have emerged depending on the optimum nutrient concentration for growth: oligotrophs thrive in low nutrient concentration whilst copiotrophs require nutrient rich environments. However, bacteria express multiple transporters, suggesting an adaptation to gradients of dissolved organic matter (Azam et al., 1995; Azam and Malfatti, 2007). Organic matter in seawater contains large amounts of transparent gels, in the form of colloids, mucous sheets and bundles, produced by microorganisms and phytoplankton. Bacterial cells may have an easy access to this nutrient pool by attaching to the gels and hydrolyzing the nutrients using cell-surface hydrolases (Smith et al., 1992; Azam et al., 1995; Long and Azam, 1996; Azam and Malfatti, 2007). These transparent exopolymer particles not only act as support for bacterial colonization, but also adsorb and transport solutes, aggregate solid particles and, by promoting the sedimentation of particles, contribute to the fluxes of carbon into deep water (Kiørboe, 2000; Passow, 2002).

Bacterial aggregates were also involved in the return to the seafloor of hydrocarbons released during the largest marine oil spill following the Deepwater Horizon accident (Passow, 2016). Although the lower density of hydrocarbons led them toward the surface, a significant fraction returned to the seafloor in a process mediated by marine snow which also contains decaying material. Three to four weeks after the spill, uncommonly large marine snow particles (in the $\mathrm{mm}$ to $\mathrm{cm}$ scale) were abundantly 
sinking (Passow et al., 2012). Laboratory experiments suggest that bacteria actively participated in the formation of mucus webs while using some of the components of the oil, concomitantly to the formation of aggregates due to collision and sticking of particles and to the action of cyanobacteria (Passow et al., 2012).

Particle associated bacteria are metabolically more active than planktonic cells, presenting high hydrolytic enzymatic activities (Smith et al., 1995). Several bacterial strains, such as those belonging to Roseobacter, produce acylated homoserine lactones as communication signals when attached to marine snow aggregates (Gram et al., 2002). Quorum sensing molecules, either retrieved directly from marine snow particles present in surface water or produced by Pantoea ananatis B9, which also colonizes natural snow particles, can enhance the performance of extracellular hydrolytic enzymes such as alkaline phosphatase (Jatt et al., 2015). In fact, hydrolytic pathways involving phosphatases, aminopeptidases and lipases can be influenced within a few hours of contact with acylated homoserine lactones, indicating that microorganisms can dynamically adjust their metabolic pathways as response to quorum sensing (Krupke et al., 2016).

The extracellular polymeric substances (EPS) produced by the microorganisms have similar roles both in marine snow and in biofilms: besides adsorbing and transporting solutes and microorganisms, they also act as a protective "roof" for cells, especially in extreme environments. The organization provided by the EPS helps (i) the entrapment of nutrients and toxic compounds, (ii) the activity and stabilization of extracellular enzymes by buffering $\mathrm{pH}$ and salinity fluctuations, (iii) quorum sensing, (iv) exchange of genetic information, (v) physical anchorage, and (vi) protection from predation (de Carvalho and Fernandes, 2010; Decho and Gutierrez, 2017).

EPS are not only composed of polysaccharides, but also of proteins and in some cases lipids, nucleic acids and other biopolymers (Flemming and Wingender, 2001). Most marine bacteria produce heteropolysaccharides with 3-4 different monosaccharides, such as pentoses, hexoses, uronic acids or amino sugars, arranged in groups of repeating units (Decho and Gutierrez, 2017). The thermophilic bacterium Bacillus thermoantarcticus produces a sulfate heteropolysaccharide containing mannose and glucose, and a sulfate homopolysaccharide containing mannose as the major component (Manca et al., 1996). Sulfates, phosphates and uronic acids present in EPS are ionizable and may interact with cations such as $\mathrm{Fe}^{2+}, \mathrm{Cu}^{2+}$, and $\mathrm{Zn}^{2+}$ (van der Merwe et al., 2009), increasing the concentration of metal ions necessary for the cells in oligotrophic conditions found in many extreme environments. The EPS of thermophilic strains such as Geobacillus tepidamans may present unusual properties such as stability to high temperatures: the purified EPS showed thermal degradation at $280^{\circ} \mathrm{C}$ (Kambourova et al., 2009). During a study conducted from austral winter to early spring in the East Antarctic sea it was found that the production of EPS per unit of biomass was higher in the colder sections of the ice cores, suggesting a cryoprotectant role for sea ice biota (van der Merwe et al., 2009).

The protection provided by EPS must compensate for the large carbon and energy investment necessary for its production.
This is valid at the cellular level but also for a biotechnological application: to reach market, the EPS must be produced at high yields, and be able to compete with synthetic petrochemical products in terms of properties and cost (Nicolaus et al., 2010). Nevertheless, there is a clear interest in EPS from extremophiles for biotechnological applications (for reviews see Nichols et al., 2005; Nicolaus et al., 2010; Poli et al., 2011).

Among the best examples of protection provided by biofilms is the high survival rate of microorganisms in intertidal zones, with biofilms conferring protection against temporary stress caused by UV exposure, temporary dehydration, competition and limited access to nutrients (Ortega-Morales et al., 2010). In these environments, where cells experience rapid cold/hot temperature, high/low salinity, dried/immersed conditions, UV exposure and $\mathrm{pH}$ changes, the cells use the ability to maintain an adequate fluidity of the cellular membrane by changing the fatty acid profile of the phospholipids (de Carvalho and Caramujo, 2012). Several strains, e.g., Shewanella colwelliana and Vibrio splendidus, producing polyunsaturated fatty acids have been isolated from anoxic intertidal sediments (Freese et al., 2009). Besides, microorganisms in biofilms and mats also produce mycosporine-like amino acids (MAAs) and carotenoid pigments which protect them against UV radiation, free radicals, salinity, $\mathrm{pH}$, temperature, radioactive compounds and reactive oxygen species (de Carvalho, 2017; de Carvalho and Caramujo, 2017).

Biofilms provide protection against UV radiation by restricting penetration of the radiation through the biofilm matrix (de Carvalho, 2017). This protection could have also provided safety from the extreme and fluctuating temperature, $\mathrm{pH}$ and UV radiation of the primitive Earth (Hall-Stoodley et al., 2004). The production of specialized lipids by extremophiles found in hot vents, icy waters near the poles, acidic and alkaline waters and brines, also plays an important role (de Carvalho and Caramujo, 2012). Several psychrophilic bacterial strains contain polyketide synthase, a novel enzyme family necessary for the production of polyunsaturated fatty acids at low temperatures, whilst Thermotoga maritima, which grows at $90^{\circ} \mathrm{C}$, contains a novel glycerol ether lipid called 15,16-dimethyl-30-glyceryloxytriacontanedioic acid (De Rosa et al., 1989; Metz et al., 2001). Besides, bacterial cells may adjust their fatty acid profile during biofilm formation on metallic and non-metallic surfaces, resulting in diverse biofilm architectures (Rodrigues and de Carvalho, 2015).

\section{MARINE BIOFILMS CAUSE BIOFOULING}

Bacteria form multispecies biofilms with other microorganisms. Bacteria and microalgae are responsible for microfouling and allow the adhesion of larger organisms such as algae, mussels and barnacles which cause macrofouling (Figure 2). They adhere to almost all surfaces immersed in seawater, such as pipes and ship hulls. The costs associated with biofilms attached to ship hulls are mainly due to increased fuel consumption resulting from higher frictional drag, although the costs for hull cleaning, coating and painting may also be considerable. It was estimated in 2010, by the US Navy, that the overall cost 


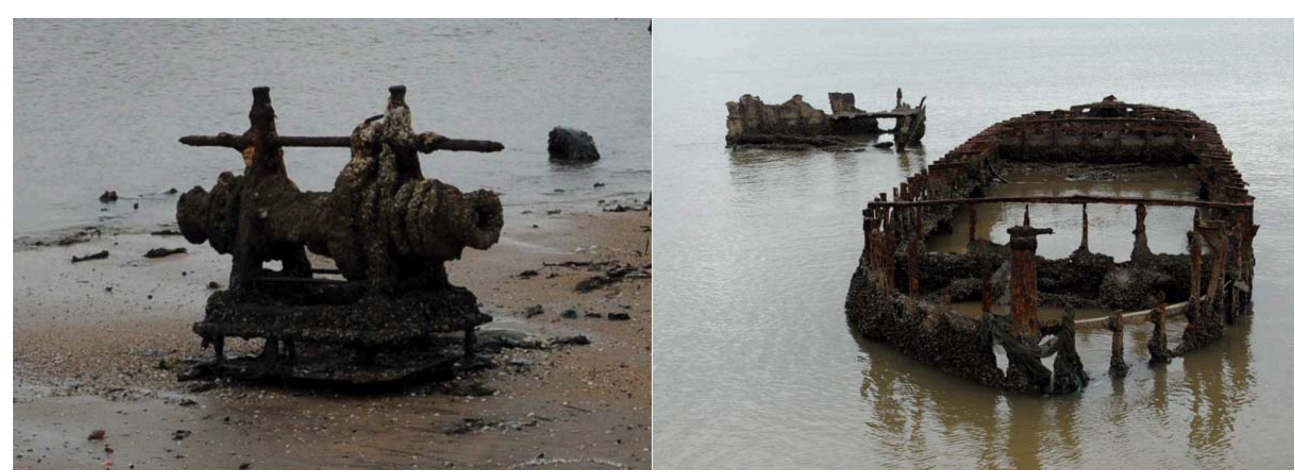

FIGURE 2 | Micro and macrofouling enhance corrosion of materials in the marine environment. (Left) Anchor windlass (Right) Ship hull.

related to hull fouling for the entire mid-sized naval surface ship class DDG-51 was 56 million dollars per year and for the entire US Navy surface fleet was calculated to be 180260 million dollars (Schultz et al., 2011). Although organisms such as mussels and barnacles are responsible for macrofouling, and thus for the diminished hydrodynamic performance of a ship, microorganisms contribute to microfouling, and have an important role in surface colonization.

Microfouling studies have described the following sequence of microbial colonization: bacteria, yeast, heterotrophic flagellates, diatoms and ciliates in artificial substrates in the Black Sea; bacteria, diatoms, autotrophic flagellates, heterotrophic flagellates and ciliates in the White Sea and Miami Beach in the Atlantic Ocean; bacteria, diatoms and protozoa in metallic surfaces (Redfield and Deevy, 1952; Gorbenko, 1977; Little and Wagner, 1997; Railkin, 1998, 2003). However, it has also been shown that diatoms can attach directly to clean surfaces such as stainless steel and glass just after a few hours of immersion (Cooksey and Wigglesworth-Cooksey, 1995). Nevertheless, considering that $1 \mu \mathrm{L}$ of surface seawater may contain ca. 10,000 viruses; 1,000 bacteria; 110 cyanobacteria; 10 eukaryotic algae and 10 protists (Azam and Malfatti, 2007), not only cell-surface but also cell-cell interactions should influence adhesion. Karpov et al. (2012) proposed the following types of biofilms observed during the first stage of fouling: type I is a film containing only living and dead bacterial cells over a surface; type II is a film of diatoms deposited on top of the bacterial layer; and type III is formed when related species settle on top of the diatom layer (Karpov et al., 2012). The latter type reached $4.5 \mathrm{~mm}$ in 10-15 days on surfaces immersed in the tropical South China Sea.

High-throughput DNA sequencing technologies have confirmed the importance of bacteria in biofilms in artificial surfaces and the resistance of these cells to surfaces with antimicrobial coatings. Proteobacteria and especially $\gamma$ proteobacteria dominated biofilm communities colonizing artificial surfaces in Toulon and Lorient, France (Briand et al., 2017), and in Mauritian coastal waters (Rampadarath et al., 2017). DNA metabarcoding showed that the proportion of $\gamma$-proteobacteria increased and dominated artificial surfaces with cupreous anti-fouling coating treatments (von Ammon et al., 2018).16S rRNA gene metabarcoding showed that proteobacteria dominated bacterial communities in used reverse osmosis membranes in a desalination plant, with $\beta$-proteobacteria being found in severely fouled membranes (Nagaraj et al., 2017). However, the community composition and diversity obtained by high throughput DNA sequencing technologies of biofilms is dependent on the DNA extraction method selected (Corcoll et al., 2017). As noted by Corcoll et al., biofilm EPS may bind DNA, while extraction methods may present different capacities to extract DNA from microorganisms with strong membranes and/or cell walls.

Bacteria can also easily colonize pipes and heat exchangers where they stimulate the settlement of the larvae of invertebrates (Railkin, 2003). As presented in a review, biofilms in general induce larval and spore settlement of macrofoulers, although negative and neutral effects have also been reported (Salta et al., 2013). However, the contradictory effects may result from differences in experimental procedures used in the few studies dedicated to assess the effect of biofilms on macrofouling settlement. Nevertheless, the local environmental and hydrodynamic conditions seem to influence both micro and macrofoulers.

Curiously, containerships which travel at relatively high speeds and remain in ports for short periods seem to be less colonized than other types of ships (Davidson et al., 2009). In a study involving 22 containerships, in San Francisco Bay, with submerged surface areas larger than $7,000 \mathrm{~m}^{2}$, less than $1 \%$ of the exposed hull was colonized except in one vessel which had nearly $90 \%$ of the hull covered (Davidson et al., 2009). The latter ship was significantly smaller than its counterparts, had shorter voyage range and traveled at slower speeds. It was also found that organisms, primarily green algae and barnacles but also hydroids, bryozoans, bivalves and ascidians, were mainly positioned in protected areas such as rudders, stern tubes, and intake gratings.

One important characteristic of biofilms is their ability to change the properties of the surface to which they are attached. However, it has also been shown that different species present diverse morphologies and cell-cell interactions while colonizing hydrophobic and hydrophilic surfaces and their early 
colonization behavior may not be sufficient to predict subsequent biofilm development (Dalton et al., 1996). Formation of natural films containing organic matter, and especially of biofilms, on surfaces immersed in seawater can change the adhesion forceinterfacial energy: while strong hydrophobic interactions can be reduced, weaker forces on hydrophilic surfaces can be enhanced (Johnson and Azetsu-Scott, 1995). To study the physico-chemical properties of the cell surfaces of early adherent marine bacteria, Grasland et al. determined the hydrophilic, electrostatic and the Lewis acid-base interactions (Grasland et al., 2003). The authors found that of the 16 bacterial strains tested, 11 possessed a hydrophilic surface and 5 showed a weak or strong hydrophobic surface, but they all adhered to a hydrophilic support after $6 \mathrm{~h}$ of immersion. In addition, all strains showed an isoelectric point between 2.2 and 3.4 and were negatively charged at the $\mathrm{pH}$ of seawater but some could not generate Lewis acid-base interactions although the majority of the strains possessed an electron-donating character.

One of the largest problems mankind will have to solve in a near future is the supply of drinking water to a growing world population. One of the main technologies for producing fresh water uses saline water and wastewater treated by reverse osmosis. In this process, water passes through a membrane (made of e.g., cellulose acetate, triacetate, or cellulose diacetate) which rejects dissolved compounds in the feeding water. If these solutes adsorb reversibly or irreversibly to the membrane, an increased overall membrane resistance is observed and fouling or biofouling occurs, depending on the chemical nature of the compounds adsorbed (Al-Ahmad et al., 2000). Biofouling is the most serious problem because it decreases water flux, increases pressure drop in the membrane modules, decreases salt rejection, and leads to membrane biodegradation and failure (Al-Ahmad et al., 2000; Peña et al., 2013).

In a study conducted to identify the bacteria responsible for membrane biofouling in seawater reverse osmosis, samples from 5 desalination plants located in diverse parts of the world were collected (Zhang et al., 2011). The results showed that bacterial communities from the membranes were not similar but some dominant bacteria were commonly observed, whereas bacterial populations in the source seawater were significantly different and dependent on location and season. Autopsies of 500 membrane elements showed that the main reason for membrane fouling in $60 \%$ of the membranes was biological/organic and particulate/colloidal matter, while inorganic fouling was observed in $22 \%$ of the membranes, and metals in 10\% (Peña et al., 2013). In 30\% of membranes with biofilms, fouling on the spacer was also observed, in $37 \%$ of membranes lower flow values were attained, and in $47 \%$ poor salt rejection was observed. However, membranes with biofilms have minor physical integrity failures indicating that their performance could be recovered by cleaning. Membrane scaling and metal fouling cause significant irreparable damage.

The very high demand for cooling water and the increased value of freshwater have favored the location of power plants in coastal areas where seawater is available at low costs. However, the problems related to biofouling of heat exchanger units are considerable. On heat exchangers, biofouling decreases heat transfer efficiency. The thermal conductivity of iron oxide is $2.9 \mathrm{Wm}^{-1} \mathrm{~K}^{-1}$ but for biofilm the corresponding value is 0.6 $\mathrm{Wm}^{-1} \mathrm{~K}^{-1}$ (Flynn, 2009), making the latter even more insulating. Furthermore, biofouling causes scaling and corrosion because, as the biofilm thickens, less oxygen is accessed by the cells next to the tube wall. Bacteria such as sulfate-reducing strains generate metabolites that attack the metal in a process called microbiologically influenced corrosion. Studies carried out in the 1980s and early 1990s, estimated that the costs of cleaning, fluid treatment, replacement of parts and loss of production due to heat exchanger fouling is ca. $0.25 \%$ of the GDP of industrialized countries (Müller-Steinhagen et al., 2005; and references within). For a process plant, the estimated cost for repairing heat exchangers and boilers is ca. $15 \%$ of the maintenance costs, and about half of this value is due to fouling (Ibrahim, 2012).

\section{MARINE BIOFILMS CAUSE BIOCORROSION}

The Worldwide Corrosion Authority, NACE International, estimated in 2016 that the global cost of corrosion is ca. 2.5 trillion USD (NACE_International, 2016). The impact of corrosion was found to be particularly important in oil and gas production, storage and transportation, and drinking and waste water industries.

Microbes have an important role in bioremediation of oil compounds, but microbial contamination of oil and natural gas facilities is undesired because they may metabolize hydrocarbons, change sulfur content, and influence oil density and viscosity. The anaerobic conditions found in the oil industry, combined with the large availability of substrates for microorganisms (e.g., hydrocarbons and organosulfur compounds), favor the appearance of biofilms causing microbial influenced corrosion (Vigneron et al., 2016; Abu Bakar et al., 2017; Li et al., 2017). However, aerobic microorganisms such as Pseudomonas sp. SS304 may also induce corrosion (Yuan et al., 2008). In samples from 3 anaerobic biofilms collected inside a heavily corroded steel pipe in an offshore oil facility in the Gulf of Mexico, bacteria represented more than $98 \%$ of the microbial population estimated by qPCR but archaea species could also be detected (Vigneron et al., 2016). Bacteria was represented mainly by the genus Desulfovibrio. Sulfate-, elemental sulfur-, and iron-reducing microorganisms were the main population in the biofilms and were probably responsible for the high corrosion rate observed and for the corrosive products detected. Acetic acid producing bacteria such as Acetobacter spp. and Gluconacetobacter spp. have been identified as main contributors to corrosion in tanks containing fuel-grade ethanol (Williamson et al., 2015), while hydrogen sulfide producing strains of the genus Acidithiobacillus were found able to corrode concrete sewers (Jiang et al., 2016). Nevertheless, several bacterial strains with corrosion-protecting effects have been identified: Vibrio neocaledonicus reduced corrosion of ASTM A36 steel by 64fold (Moradi et al., 2015); and Pseudomonas S9 and Serratia marcescens EF190 decreased corrosion of ASTM A619 carbon 
steel under aerobic conditions (Pedersen and Hermansson, 1989). The three possible mechanisms that may be related to the inhibition of biofilm-induced metal corrosion are: removal of toxic compounds; inhibition of growth of microbes responsible for corrosion by their non-corrosive counterparts; and formation of a protective layer by overproduction of EPS by non-corrosive microbes (Zuo, 2007).

\section{PREVENTING BIOFOULING AND BIOCORROSION}

The International Maritime Organization has established a series of guidelines, published as resolution MEPC.207(62), for the control and management of biofouling of ships aiming at preventing the transfer of invasive aquatic species (IMO, 2011). The implementation of an effective biofouling management regime includes a management plan and record book for each ship containing e.g., information regarding susceptible places for colonization, scheduled of planned inspections, and anti-fouling treatments used.

Several preventive paints and coatings have been developed to prevent microbial adhesion. Copper coatings, as well as coatings with other toxic compounds such as arsenic, tin and mercury, were used until their toxic effects to the marine environment became known. New non-toxic "green" antifouling coatings have been sought, and effective ones include: silicone based materials such as poly(dimethylsiloxane) based coatings; fluorine based materials as poly(tetrafluoro ethylene); and combined fluorine-silicon based materials that associate the low critical surface tension of silicon-based materials and the rigidity of fluorinated compounds (Nurioglu et al., 2015). Graphenecoated materials are a promising strategy since the material surface energy and electrostatic interaction between material and bacteria are affected at a nanomolecular scale (Parra et al., 2015). Nevertheless, hull cleaning usually has to be done at some point regardless of the fouling-control coating used on a ship. To avoid decreasing the lifetime of the coating, minimum cleaning forces should be applied, according to the adhesion strength of marine organisms attached to the hull (Oliveira and Granhag, 2016).

A non-evasive, clean and promising technology uses ultrasounds to control biofilm formation (Zips et al., 1990; Wang et al., 2017; Park and Lee, 2018). A $23 \mathrm{kHz}$ sinusoidal ultrasound emitted by 6 projectors at $214 \mathrm{~dB}$ around the starboard shell plane of a $96,000 \mathrm{~m}^{3}$ class drill-ship was efficient to prevent the settlement of fouling organisms (Park and Lee, 2018). After 4 months, clean areas could be observed on the starboard side but heavy fouling covered the port side. The different parameters and equipment used in the several studies published complicate the assessment of the best conditions to prevent biofouling, however, the majority of the studies used frequencies between 17 and $30 \mathrm{kHz}$ (Legg et al., 2015).

Electrolytic systems have also been applied to prevent biofouling on ship hulls. In an underwater experiment carried out in 1972, $36 \mathrm{~m}$ long electrodes were fitted longitudinally to the bilge of a 126,000 ton ship under construction (Yoshii et al., 1972). This allowed uniform distribution of chlorine which acted as antimicrobial agent. Cathodic protection has also been used on ships, and a combination of cathodic protection and coating is regarded as the most effective antifouling process (Siewert, 2004). The current applied to achieve cathodic protection is critical: for bare steel in wavy and rough seas the current needed is 350 $\mathrm{mA} / \mathrm{m}^{2}$ and after polarization $100 \mathrm{~mA} / \mathrm{m}^{2}$ should be maintained; for coated steel a current of $50 \mathrm{~mA} / \mathrm{m}^{2}$ should be applied in wavy and rough seas, and after polarization it should be decreased to $15 \mathrm{~mA} / \mathrm{m}^{2}$ (Cicek, 2017b).

Biocides for the petroleum and gas mining industry should present a broad spectrum of activity for extended periods, good solubility in both water and hydrocarbons, and chemical and thermal stability, while being environmentally friendly, effective at concentrations below $100 \mathrm{ppm}$, and made from cheap and accessible materials (Turkiewicz et al., 2013). A cathodic protection current of $40 \mathrm{~mA} / \mathrm{m}^{2}$ may be initially applied to oil storage tanks and reduced after 2 months to $20 \mathrm{~mA} / \mathrm{m}^{2}$ for a period of 10 years if sacrificial aluminum anodes are used (Cicek, 2017a).

To improve the efficiency of the reverse osmosis process, pretreatments, new modules and antifouling membranes have been developed (Kang and Cao, 2012). Improvements made in reverse osmosis membranes include the following: new interfacial polymerization monomers, usually with more functional or polar groups to increase hydrophilicity; better polymerization processes to increase hydrophilicity, reduce roughness and enhance antifouling by the addition of structures such as polymer brushes; surface modification through physical adsorption of e.g., surfactants or chemical treatment; and surface coating with compounds that act as a protective layer (Kang and Cao, 2012). When a biofilm is installed, membrane cleaning may represent $5-20 \%$ of operating costs and may be performed by chemical cleaning agents such as acids, metal chelating agents, and enzymes (Maddah and Chogle, 2017). Although pretreatment strategies may be efficient in removing nearly all bacterial cells, the few that survive may multiply on the membrane surface and cause biofouling. The preferred pretreatment methods to disinfect the water in the feed current include the following: oxidizing agents such as chlorine, bromine, chlorine dioxide, hydrogen peroxide and ozone; non-oxidizing agents such as formaldehyde, glutaraldehyde and quaternary ammonium compounds; thermal treatment especially in systems using direct sunlight; UV light which presents low cost and easy implementation but may have limited efficiency due to suspended compounds; electrical methods involving electrochemical techniques or pulsed electric field; and ultrasound techniques such as acoustic cavitation (for reviews see e.g., Ahmad et al., 2012; Al-Juboori and Yusaf, 2012; Maddah and Chogle, 2017).

A study conducted in the coastal waters of Kalpakkam, India, near the Madras Atomic Power Station, which used seawater at $35 \mathrm{~m}^{3} \mathrm{~s}^{-1}$ as coolant for the condenser and process cooling water systems, suggested: high flow rates so that shear stress surpasses the shear strength of many organisms; thermal treatment (although the power station has to decrease activity during the disinfection period); manual and mechanical methods which may be costly; variations in salinity; application of ozone; 
bioactive compounds and chemical compounds such as iodine, hydrogen peroxide and potassium permanganate, as efficient methods to prevent micro and macrofouling (Satpathy et al., 2010). However, biofouling control by chlorination seemed to give the best results. It is still the most common method in cooling water systems worldwide, although legislation in several countries limits the concentration of chlorine that may be applied.

Numerous strategies to prevent biofilm formation and to remove established biofilms have been tested and developed under laboratory conditions. Among these are the following: use of specific enzymes such as proteases and oxidases; application of quorum sensing inhibitors; coatings with microcapsules containing biocides; and use of bacteriophages (for reviews see Dobretsov et al., 2009, 2013; de Carvalho, 2012b; Sadekuzzaman et al., 2015). However, not all of these represent strategies that are technical and/or economical feasible at large scale in the near future. Furthermore, the impact to the natural environment of e.g., quorum sensing inhibitors used in aquaculture facilities, and biocides released from coatings, is still unknown.

\section{MARINE BIOFILMS MAY BE USED IN BIOREMEDIATION}

The ability of cells to degrade petroleum hydrocarbons has been used for the bioremediation of contaminated polluted sites (de Carvalho et al., 2009; Atlas and Hazen, 2011; Tyagi et al., 2011; de Carvalho, 2012a). During the two most important accidents in the oil industry in the US, the Exxon Valdez and the BP Deepwater Horizon spills, microbes played a paramount role in reducing the environmental impact in the marine ecosystems. Contaminated sites usually have enough carbon sources but marine environments are usually poor in nitrates, phosphates and iron, which may limit microbial growth. The strategies used in the two oil spills were different. An estimated 42 million liters of heavy crude oil was spilled by the Exxon Valdez in 1989 near the shore, and due to weather conditions and nature of the oil, dispersants were not used and a significant part of the oil float ashore (Atlas and Hazen, 2011). Two fertilizers were used to enhance bioremediation, and the initial naturally oil-degrading bacteria present at $1-5 \times 10^{3}$ cells/mL of seawater $(1-10 \%$ of

\section{REFERENCES}

Abu Bakar, A., Ali, M., Noor, N. M., Yahaya, N., Ismail, M., and Abdullah, A. (2017). Bio-corrosion of carbon steel by sulfate reducing bacteria consortium in oil and gas pipelines. J. Mech. Eng. Sci. 11, 2592-2600. doi: 10.15282/jmes.11.2.2017.3.0237

Ahmad, A. L., Che Lah, N. F., Ismail, S., and Ooi, B. S. (2012). Membrane antifouling methods and alternatives: ultrasound approach. Sep. Purif. Rev. 41, 318-346. doi: 10.1080/15422119.2011.617804

Al-Ahmad, M., Abdul Aleem, F. A., Mutiri, A., and Ubaisy, A. (2000). Biofuoling in RO membrane systems Part 1: fundamentals and control. Desalination 132, 173-179. doi: 10.1016/S0011-9164(00)00146-6

Al-Juboori, R. A., and Yusaf, T. (2012). Biofouling in RO system: mechanisms, monitoring and controlling. Desalination 302(Suppl. C), 1-23. doi: 10.1016/j.desal.2012.06.016 total heterotrophic population) increased to $1 \times 10^{5}$ cells $/ \mathrm{mL}$ (40\% of the total heterotrophic population) by late 1989 . Between 1989 and 1991, 48.6 tons of fertilizers were applied and by June 1992 the cleanup was considered concluded. During the 2010 accident in BP's Deepwater Horizon, an estimated 780 million liters of light Louisiana crude oil were released (with 0.8 million barrels being recovered before reaching the water column) at a depth of more than 5,000 $\mathrm{m}$ (Atlas and Hazen, 2011). One of the strategies used was to inject dispersant directly at the wellhead at a water depth of $1,500 \mathrm{~m}$. Together with the physical dispersion, due to pressure and temperature, this resulted in a "cloud" of dispersed oil observed between 900 and $1,300 \mathrm{~m}$, containing up to $10^{5}$ cells $/ \mathrm{mL}$. During the time oil was being released, the halflife of alkanes ranged between 1.2 and 6.1 days in the "cloud," and the concentration of polynuclear aromatic hydrocarbons was less than $1.0 \mathrm{ppb}$ at a distance of ca. $30 \mathrm{~km}$.

\section{FINAL REMARKS}

Several of the methods used by the different industries are satisfactory to minimize the impact of biofilms. However, in most cases, only substitution of expensive equipment or parts can solve the problem. The quest for novel and environment friendly methods to prevent biofilm formation and to clean infected sites and materials may be a long-running one, as fossils of biofilms with more than 3 billion years old show the success of these microbial communities and their adaptability.

\section{AUTHOR CONTRIBUTIONS}

The author did the bibliographic review and wrote the manuscript.

\section{ACKNOWLEDGMENTS}

The author acknowledges Fundação para a Ciência e a Tecnologia, I.P. (FCT), Portugal, for financial support under program Investigador FCT 2013 (IF/01203/2013/CP1163/CT0002) and UID/BIO/04565/2013, and the EU for partially supporting the study under grant agreement no. 634486 (Project INMARE).
Atlas, R. M., and Hazen, T. C. (2011). Oil biodegradation and bioremediation: a tale of the two worst spills in U.S. history. Environ. Sci. Technol. 45, 6709-6715. doi: 10.1021/es2013227

Azam, F., Fenchel, T., Field, J. G., Gray, J. S., Meyer-Reil, L. A., and Thingstad, F. (1983). The ecological role of water-column microbes in the sea Mar. Ecol. Prog. Ser. 10, 257-263. doi: 10.3354/meps010257

Azam, F., and Malfatti, F. (2007). Microbial structuring of marine ecosystems. Nat. Rev. Microbiol. 5, 782-791. doi: 10.1038/ nrmicro1747

Azam, F., Smith, D. C., Long, R. A., and Steward, G. F. (1995). "Bacteria in oceanic carbon cycling as a molecular problem," in Molecular Ecology of Aquatic Microbes, ed I. Joint (Berlin; Heidelberg: Springer), 39-54.

Bijlsma, R., and Loeschcke, V. (2005). Environmental stress, adaptation and evolution: an overview. J. Evol. Biol. 18, 744-749. doi: 10.1111/j.1420-9101.2005.00962.x 
Briand, J. F., Barani, A., Garnier, C., Réhel, K., Urvois, F., LePoupon, C., et al. (2017). Spatio-temporal variations of marine biofilm communities colonizing artificial substrata including antifouling coatings in contrasted French coastal environments. Microb. Ecol. 74, 585-598. doi: 10.1007/s00248-017-0966-2

Brooks, A. N., Turkarslan, S., Beer, K. D., Lo, F. Y., and Baliga, N. S. (2011). Adaptation of cells to new environments. Wiley Interdiscip. Rev. Syst. Biol. Med. 3, 544-561. doi: 10.1002/wsbm.136

Brown, M. R., and Williams, P. (1985). The influence of environment on envelope properties affecting survival of bacteria in infections. Annu. Rev. Microbiol. 39, 527-556. doi: 10.1146/annurev.mi.39.100185.002523

Cao, S., Wang, J., Chen, H., and Chen, D. (2011). Progress of marine biofouling and antifouling technologies. Chin. Sci. Bull. 56, 598-612. doi: 10.1007/s11434-010-4158-4

Cicek, V. (ed.). (2017a). "Corrosion and cathodic protection of crude oil or petroleum storage tanks," in Corrosion Engineering and Cathodic Protection Handbook (Hoboken, NJ: John Wiley and Sons, Inc.), 187-190. doi: $10.1002 / 9781118737880 . c h 16$

Cicek, V. (ed.). (2017b). "Corrosion and cathodic protection of metallic structures in seawater," in Corrosion Engineering and Cathodic Protection Handbook (Hoboken, NJ: John Wiley and Sons, Inc.), 191-196. doi: 10.1002/9781119284338.ch31

Claessen, D., Rozen, D. E., Kuipers, O. P., Søgaard-Andersen, L., and van Wezel, G. P. (2014). Bacterial solutions to multicellularity: a tale of biofilms, filaments and fruiting bodies. Nat. Rev. Microbiol. 12, 115-124. doi: 10.1038/ nrmicro3178

Cooke, W. M. B. (1956). Colonization of artificial bare areas by microorganisms. Bot. Rev. 22, 613-638. doi: 10.1007/BF02872373

Cooksey, K. E., and Wigglesworth-Cooksey, B. (1995). Adhesion of bacteria and diatoms to surfaces in the sea: a review. Aquat. Microb. Ecol. 09, 87-96. doi: $10.3354 /$ ame009087

Corcoll, N., Österlund, T., Sinclair, L., Eiler, A., Kristiansson, E., Backhaus, T., et al. (2017). Comparison of four DNA extraction methods for comprehensive assessment of $16 \mathrm{~S}$ rRNA bacterial diversity in marine biofilms using high-throughput sequencing. FEMS Microbiol. Lett. 364:fnx139. doi: $10.1093 /$ femsle/fnx139

Costerton, J. W., Geesey, G. G., and Cheng, K. J. (1978). How bacteria stick. Sci. Am. 238, 86-95. doi: 10.1038/scientificamerican0178-86

Costerton, J. W., Lewandowski, Z., Caldwell, D. E., Korber, D. R., and LappinScott, H. M. (1995). Microbial biofilms. Annu. Rev. Microbiol. 49, 711-745. doi: 10.1146/annurev.mi.49.100195.003431

Dalton, H. M., Goodman, A. E., and Marshall, K. C. (1996). Diversity in surface colonization behavior in marine bacteria. J. Ind. Microbiol. 17, 228-234. doi: 10.1007/BF01574697

Dang, H., Li, T., Chen, M., and Huang, G. (2008). Cross-ocean distribution of Rhodobacterales bacteria as primary surface colonizers in temperate coastal marine waters. Appl. Environ. Microbiol. 74, 52-60. doi: 10.1128/AEM.01400-07

Dang, H., and Lovell, C. R. (2016). Microbial surface colonization and biofilm development in marine environments. Microbiol. Mol. Biol. Rev. 80, 91-138. doi: 10.1128/MMBR.00037-15

Davidson, I. C., Brown, C. W., Sytsma, M. D., and Ruiz, G. M. (2009). The role of containerships as transfer mechanisms of marine biofouling species. Biofouling 25, 645-655. doi: 10.1080/08927010903046268

de Carvalho, C. C. C. R. (2012a). Adaptation of Rhodococcus erythropolis cells for growth and bioremediation under extreme conditions. Res. Microbiol. 163, 125-136. doi: 10.1016/j.resmic.2011.11.003

de Carvalho, C. C. C. R. (2012b). Biofilms: new ideas for an old problem. Recent Pat. Biotechnol. 6, 13-22. doi: 10.2174/187220812799789163

de Carvalho, C. C. C. R. (2017). "Biofilms: microbial strategies for surviving UV exposure," in Ultraviolet Light in Human Health, Diseases and Environment, ed S. I. Ahmad (Cham: Springer International Publishing), 233-239.

de Carvalho, C. C. C. R., and Caramujo, M. J. (2012). Lipids of prokaryotic origin at the base of marine food webs. Mar. Drugs 10, 2698-2714. doi: $10.3390 / \mathrm{md} 10122698$

de Carvalho, C. C. C. R., and Caramujo, M. J. (2017). Carotenoids in aquatic ecosystems and aquaculture: a colorful business with implications for human health. Front. Mar. Sci. 4:93. doi: 10.3389/fmars.2017.00093 de Carvalho, C. C. C. R., and da Fonseca, M. M. R. (2007). Preventing biofilm formation: promoting cell separation with terpenes. FEMS Microbiol. Ecol. 61, 406-413. doi: 10.1111/j.1574-6941.2007.00352.x

de Carvalho, C. C. C. R., and Fernandes, P. (2010). Production of metabolites as bacterial responses to the marine environment. Mar. Drugs 8, 705-727. doi: $10.3390 / \mathrm{md} 8030705$

de Carvalho, C. C. C. R., Wick, L. Y., and Heipieper, H. J. (2009). Cell wall adaptations of planktonic and biofilm Rhodococcus erythropolis cells to growth on C5 to C16 n-alkane hydrocarbons. Appl. Microbiol. Biotechnol. 82, 311-320. doi: 10.1007/s00253-008-1809-3

Decho, A. W., and Gutierrez, T. (2017). Microbial extracellular polymeric substances (EPSs) in Ocean systems. Front. Microbiol. 8:922. doi: $10.3389 /$ fmicb. 2017.00922

de la Fuente-Núñez, C., Korolik, V., Bains, M., Nguyen, U., Breidenstein, E. B., Horsman, S., et al. (2012). Inhibition of bacterial biofilm formation and swarming motility by a small synthetic cationic peptide. Antimicrob. Agents Chemother. 56, 2696-2704. doi: 10.1128/AAC.00064-12

De Rosa, M., Gambacorta, A., Huber, R., Lanzotti, V., Nicolaus, B., Stetter, K. O., et al. (1989). "Lipid structure in Thermotoga maritima," in Microbiology of Extreme Environments and its Potential for Biotechnology, eds M. S. da Costa, J. C. Duarte, and R. A. D. Williams (Rotterdam: Springer), 167-173.

Dobretsov, S., Abed, R. M., and Teplitski, M. (2013). Mini-review: inhibition of biofouling by marine microorganisms. Biofouling 29, 423-441. doi: 10.1080/08927014.2013.776042

Dobretsov, S., Teplitski, M., and Paul, V. (2009). Mini-review: quorum sensing in the marine environment and its relationship to biofouling. Biofouling 25, 413-427. doi: 10.1080/08927010902853516

Donlan, R. M. (2001). Biofilm formation: a clinically relevant microbiological process. Clin. Infect. Dis. 33, 1387-1392. doi: 10.1086/322972

Fernandes, J. A., Santos, L., Vance, T., Fileman, T., Smith, D., Bishop, J. D. D., et al. (2016). Costs and benefits to European shipping of ballast-water and hullfouling treatment: impacts of native and non-indigenous species. Mar. Policy 64(Suppl. C), 148-155. doi: 10.1016/j.marpol.2015.11.015

Fitridge, I., Dempster, T., Guenther, J., and de Nys, R. (2012). The impact and control of biofouling in marine aquaculture: a review. Biofouling 28, 649-669. doi: 10.1080/08927014.2012.700478

Flemming, H. C. (1997). Reverse osmosis membrane biofouling. Exp. Therm. Fluid Sci. 14, 382-391. doi: 10.1016/S0894-1777(96)00140-9

Flemming, H. C. (2016). EPS - then and now. Microorganisms 4:41. doi: $10.3390 /$ microorganisms 4040041

Flemming, H. C., and Wingender, J. (2001). Relevance of microbial extracellular polymeric substances (EPSs) - Part I: Structural and ecological aspects. Water Sci. Technol. 43, 1-8.

Flemming, H. C., and Wingender, J. (2010). The biofilm matrix. Nat. Rev. Microbiol. 8, 623-633. doi: 10.1038/nrmicro2415

Fletcher, M. (1991). "The physiological activity of bacteria attached to solid surfaces," in Advances in Microbial Physiology, eds A. H. Rose and D. W. Tempest (London: Academic Press Limited), 53-85.

Floerl, O., Sunde, L., and Bloecher, N. (2016). Potential environmental risks associated with biofouling management in salmon aquaculture. Aquac. Environ. Interact. 8, 407-417. doi: 10.3354/aei00187

Flynn, D. (2009). Nalco Water Handbook, 3rd Edn. New York, NY: McGraw-Hill.

Freese, E., Rütters, H., Köster, J., Rullkötter, J., and Sass, H. (2009). Gammaproteobacteria as a possible source of eicosapentaenoic acid in anoxic intertidal sediments. Microb. Ecol. 57, 444-454. doi: 10.1007/s00248-008-9443-2

Furey, P. C., Liess, A., and Lee, S. (2017). Substratum-associated microbiota. Water Environ. Res. 89, 1634-1675. doi: 10.2175/106143017X15023776270610

Giraud, X., Le Quéré, C., and da Cunha, L. C. (2008). Importance of coastal nutrient supply for global Ocean biogeochemistry. Global Biogeochem. Cycles 22:GB2025. doi: 10.1029/2006GB002717

Gorbenko, Y. A. (1977). Ekologiya Morskikh Mikroorganizmov Perifitona (Ecology of Microogranisms of Marine Periphyton). Kiev: Nauk.

Gram, L., Grossart, H. P., Schlingloff, A., and Kiørboe, T. (2002). Possible quorum sensing in marine snow bacteria: production of acylated homoserine lactones by Roseobacter strains isolated from marine snow. Appl. Environ. Microbiol. 68, 4111-4116. doi: 10.1128/AEM.68.8.4111-4116.2002 
Grasland, B., Mitalane, J., Briandet, R., Quemener, E., Meylheuc, T., Linossier, I., et al. (2003). Bacterial biofilm in seawater: cell surface properties of early-attached marine bacteria. Biofouling 19, 307-313. doi: 10.1080/0892701031000121041

Gu, H., Hou, S., Yongyat, C., De Tore, S., and Ren, D. (2013). Patterned biofilm formation reveals a mechanism for structural heterogeneity in bacterial biofilms. Langmuir 29, 11145-11153. doi: 10.1021/la402608z

Hall-Stoodley, L., Costerton, J. W., and Stoodley, P. (2004). Bacterial biofilms: from the natural environment to infectious diseases. Nat. Rev. Microbiol. 2, 95-108. doi: 10.1038/nrmicro821

Hawley, A. K., Nobu, M. K., Wright, J. J., Durno, W. E., Morgan-Lang, C., Sage, B., et al. (2017). Diverse Marinimicrobia bacteria may mediate coupled biogeochemical cycles along eco-thermodynamic gradients. Nat. Commun. 8:1507. doi: 10.1038/s41467-017-01376-9

Ibrahim, H. A.-H. (2012). "Fouling in heat exchangers," in MATLAB - A Fundamental Tool for Scientific Computing and Engineering Applications, Vol. 3, ed V. N. Katsikis (Rijeka: InTech), Ch. 03.

IMO (2011). "Guidelines for the control and management of ships' biofouling to minimize the transfer of invasive aquatic species," in Resolution MEPC.207(62), ed I. M. Organization (London: IMO Publishing).

Jatt, A. N., Tang, K., Liu, J., Zhang, Z., and Zhang, X. H. (2015). Quorum sensing in marine snow and its possible influence on production of extracellular hydrolytic enzymes in marine snow bacterium Pantoea ananatis B9. FEMS Microbiol. Ecol. 91, 1-13. doi: 10.1093/femsec/fiu030

Jiang, G., Zhou, M., Chiu, T. H., Sun, X., Keller, J., and Bond, P. L. (2016). Wastewater-enhanced microbial corrosion of concrete sewers. Environ. Sci. Technol. 50, 8084-8092. doi: 10.1021/acs.est.6b02093

Johnson, B. D., and Azetsu-Scott, K. (1995). Adhesion force and the character of surfaces immersed in seawater. Limnol. Oceanogr. 40, 802-808. doi: 10.4319/lo.1995.40.4.0802

Kambourova, M., Mandeva, R., Dimova, D., Poli, A., Nicolaus, B., and Tommonaro, G. (2009). Production and characterization of a microbial glucan, synthesized by Geobacillus tepidamans V264 isolated from Bulgarian hot spring. Carbohydr. Polym. 77, 338-343. doi: 10.1016/j.carbpol.2009.01.004

Kang, G. D., and Cao, Y. M. (2012). Development of antifouling reverse osmosis membranes for water treatment: a review. Water Res. 46, 584-600. doi: 10.1016/j.watres.2011.11.041

Karpov, V. A., Kovalchuk, Y. L., Kharchenko, U. V., and Beleneva, I. A. (2012). The effect of microfouling on marine corrosion of metals and destruction of protective coatings. Prot. Met. Phys. Chem. Surf. 48, 803-809. doi: 10.1134/S207020511207009X

Kiørboe, T. (2000). Formation and fate of marine snow: small-scale processes with large-scale implications. Sci. Mar. 65(Suppl. 2), 57-71. doi: $10.3989 /$ scimar.2001.65s 257

Krupke, A., Hmelo, L. R., Ossolinski, J. E., Mincer, T. J., and Van Mooy, B. A. S. (2016). Quorum sensing plays a complex role in regulating the enzyme hydrolysis activity of microbes associated with sinking particles in the ocean. Front. Mar. Sci. 3:55. doi: 10.3389/fmars.2016.00055

Landini, P. (2009). Cross-talk mechanisms in biofilm formation and responses to environmental and physiological stress in Escherichia coli. Res. Microbiol. 160, 259-266. doi: 10.1016/j.resmic.2009.03.001

Lane, A., and Willemsen, P. (2004). Collaborative effort looks into biofouling. Fish Farm. Int. 34-35.

Legg, M., Yücel, M. K., Garcia de Carellan, I., Kappatos, V., Selcuk, C., and Gan, T. H. (2015). Acoustic methods for biofouling control: a review. Ocean Eng. 103, 237-247. doi: 10.1016/j.oceaneng.2015.04.070

Li, X. X., Yang, T., Mbadinga, S. M., Liu, J. F., Yang, S. Z., Gu, J. D., et al. (2017). Responses of microbial community composition to temperature gradient and carbon steel corrosion in production water of petroleum reservoir. Front. Microbiol. 8:2379. doi: 10.3389/fmicb.2017.02379

Little, B. J., Lee, J. S., and Ray, R. I. (2008). The influence of marine biofilms on corrosion: a concise review. Electrochim. Acta 54, 2-7. doi: 10.1016/j.electacta.2008.02.071

Little, B. J., and Wagner, P. A. (1997). "Succession in microfouling," in Fouling Organisms in the Indian Ocean: Biology and Control Technology, eds R. Nagabhushanam and M. F. Thompson (Rotterdam: A.A. Balkema Publishers), 548

Lobelle, D., and Cunliffe, M. (2011). Early microbial biofilm formation on marine plastic debris. Mar. Pollut. Bull. 62, 197-200. doi: 10.1016/j.marpolbul.2010.10.013
Long, R. A., and Azam, F. (1996). Abundant protein-containing particles in the sea. Aquat. Microb. Ecol. 10, 213-221. doi: 10.3354/ame010213

López-Maury, L., Marguerat, S., and Bähler, J. (2008). Tuning gene expression to changing environments: from rapid responses to evolutionary adaptation. Nat. Rev. Genet. 9, 583-593. doi: 10.1038/nrg2398

MacIntyre, H. L., Geider, R. J., and Miller, D. C. (1996). Microphytobenthos: the ecological role of the "secret garden" of unvegetated, shallow-water marine habitats. I. Distribution, abundance and primary production. Estuaries 19, 186-201.

Maddah, H., and Chogle, A. (2017). Biofouling in reverse osmosis: phenomena, monitoring, controlling and remediation. Appl. Water Sci. 7, 2637-2651. doi: 10.1007/s13201-016-0493-1

Manca, M. C., Lama, L., Improta, R., Esposito, E., Gambacorta, A., and Nicolaus, B. (1996). Chemical composition of two exopolysaccharides from Bacillus thermoantarcticus. Appl. Environ. Microbiol. 62, 3265-3269.

Matz, C., Webb, J. S., Schupp, P. J., Phang, S. Y., Penesyan, A., Egan, S., et al. (2008) Marine biofilm bacteria evade eukaryotic predation by targeted chemical defense. PLoS ONE 3:e2744. doi: 10.1371/journal.pone.0002744

Metz, J. G., Roessler, P., Facciotti, D., Levering, C., Dittrich, F., Lassner, M., et al. (2001). Production of polyunsaturated fatty acids by polyketide synthases in both prokaryotes and eukaryotes. Science 293, 290-293. doi: $10.1126 /$ science. 1059593

Moradi, M., Song, Z., and Tao, X. (2015). Introducing a novel bacterium, Vibrio neocaledonicus sp. with the highest corrosion inhibition efficiency. Electrochem. Commun. 51(Suppl. C), 64-68. doi: 10.1016/j.elecom.2014. 12.007

Müller-Steinhagen, H., Malayeri, M. R., and Watkinson, A. P. (2005). Fouling of heat exchangers-new approaches to solve an old problem. Heat Transf. Eng. 26, 1-4. doi: 10.1080/01457630590889906

NACE_International (2016). International Measures Of Prevention, Application, And Economics Of Corrosion Technologies Study. Houston, TX: G. Jacobson.

Nagaraj, V., Skillman, L., Ho, G., Li, D., and Gofton, A. (2017). Characterisation and comparison of bacterial communities on reverse osmosis membranes of a full-scale desalination plant by bacterial $16 \mathrm{~S}$ rRNA gene metabarcoding. $n p j$ Biofilms Microbiomes 3:13. doi: 10.1038/s41522-017-0021-6

Nichols, C. A., Guezennec, J., and Bowman, J. P. (2005). Bacterial exopolysaccharides from extreme marine environments with special consideration of the southern Ocean, sea ice, and deep-sea hydrothermal vents: a review. Mar. Biotechnol. 7, 253-271. doi: 10.1007/s10126-004-5118-2

Nicolaus, B., Kambourova, M., and Oner, E. T. (2010). Exopolysaccharides from extremophiles: from fundamentals to biotechnology. Environ. Technol. 31, 1145-1158. doi: 10.1080/09593330903552094

Nurioglu, A. G., Esteves, A. C. C., and de With, G. (2015). Non-toxic, non-biociderelease antifouling coatings based on molecular structure design for marine applications. J. Mater. Chem. B. 3, 6547-6570. doi: 10.1039/C5TB00232J

Oliveira, D., and Granhag, L. (2016). Matching forces applied in underwater hull cleaning with adhesion strength of marine organisms. J. Mar. Sci. Eng. 4:66. doi: 10.3390/jmse4040066

Ortega-Morales, B. O., Chan-Bacab, M. J., De la Rosa-García, Sdel C., and Camacho-Chab, J. C. (2010). Valuable processes and products from marine intertidal microbial communities. Curr. Opin. Biotechnol. 21, 346-352. doi: 10.1016/j.copbio.2010.02.007

Paerl, H. W., and Pinckney, J. L. (1996). A mini-review of microbial consortia: their roles in aquatic production and biogeochemical cycling. Microb. Ecol. 31, 225-247. doi: 10.1007/BF00171569

Park, J. S., and Lee, J. H. (2018). Sea-trial verification of ultrasonic antifouling control. Biofouling 34, 98-110. doi: 10.1080/08927014.2017.1409347

Parra, C., Dorta, F., Jimenez, E., Henríquez, R., Ramírez, C., Rojas, R., et al. (2015). A nanomolecular approach to decrease adhesion of biofoulingproducing bacteria to graphene-coated material. J. Nanobiotechnol. 13:82. doi: 10.1186/s12951-015-0137-x

Passow, U. (2002). Transparent exopolymer particles (TEP) in aquatic environments. Prog. Oceanogr. 55, 287-333. doi: 10.1016/S0079-6611(02)00138-6

Passow, U. (2016). Formation of rapidly-sinking, oil-associated marine snow. Deep Sea Res. Part II Top Stud. Oceanogr. 129(Suppl. C), 232-240. doi: 10.1016/j.dsr2.2014.10.001

Passow, U., Ziervogel, K., Asper, V., and Diercks, A. (2012). Marine snow formation in the aftermath of the Deepwater Horizon oil spill in the Gulf of Mexico. Environ. Res. Lett. 7:035301. doi: 10.1088/1748-9326/7/3/035301 
Pedersen, A., and Hermansson, M. (1989). The effects on metal corrosion by Serratia marcescens and a Pseudomonas SP. Biofouling 1, 313-322. doi: 10.1080/08927018909378119

Peña, N., Gallego, S., del Vigo, F., and Chesters, S. P. (2013). Evaluating impact of fouling on reverse osmosis membranes performance. Desalination Water Treat. 51, 958-968. doi: 10.1080/19443994.2012.699509

Poli, A., Di Donato, P., Abbamondi, G. R., and Nicolaus, B. (2011). Synthesis, production, and biotechnological applications of exopolysaccharides and polyhydroxyalkanoates by Archaea. Archaea 2011:693253. doi: $10.1155 / 2011 / 693253$

Rabin, N., Zheng, Y., Opoku-Temeng, C., Du, Y., Bonsu, E., and Sintim, H. O. (2015). Biofilm formation mechanisms and targets for developing antibiofilm agents. Future Med. Chem. 7, 493-512. doi: 10.4155/fmc.15.6

Railkin, A. I. (1998). The pattern of recovery of disturbed microbial communities inhabiting hard substrates. Hydrobiologia 385, 47-57. doi: 10.1023/A:1003422129254

Railkin, A. I. (2003). Marine Biofouling: Colonization Processes and Defenses. Boca Raton, FL: CRC Press.

Rampadarath, S., Bandhoa, K., Puchooa, D., Jeewon, R., and Bal, S. (2017). Early bacterial biofilm colonizers in the coastal waters of Mauritius. Electron. J. Biotechnol. 29, 13-21. doi: 10.1016/j.ejbt.2017.06.006

Rasmussen, B. (2000). Filamentous microfossils in a 3,235-million-yearold volcanogenic massive sulphide deposit. Nature 405, 676-679. doi: $10.1038 / 35015063$

Redfield, A. C., and Deevy, E. S. Jr. (1952). Temporal Sequences and Biotic Successions, Chapter 4. Annapolis, MD: George Banta Publishing Co.

Rodrigues, C. J., and de Carvalho, C. C. C. R. (2015). Rhodococcus erythropolis cells adapt their fatty acid composition during biofilm formation on metallic and non-metallic surfaces. FEMS Microbiol. Ecol. 91: fiv135. doi: 10.1093/femsec/fiv135

Sadekuzzaman, M., Yang, S., Mizan, M. F. R., and Ha, S. D. (2015). Current and recent advanced strategies for combating biofilms. Compr. Rev. Food Sci. Food Saf. 14, 491-509. doi: 10.1111/1541-4337.12144

Salta, M., Wharton, J. A., Blache, Y., Stokes, K. R., and Briand, J. F. (2013). Marine biofilms on artificial surfaces: structure and dynamics. Environ. Microbiol. 15, 2879-2893. doi: 10.1111/1462-2920.12186

Sanli, K., Bengtsson-Palme, J., Nilsson, R. H., Kristiansson, E., Alm Rosenblad, M., Blanck, H., et al. (2015). Metagenomic sequencing of marine periphyton: taxonomic and functional insights into biofilm communities. Front Microbiol. 6:1192. doi: 10.3389/fmicb.2015.01192

Satpathy, K. K., Mohanty, A., Sahu, G., Biswas, S., and Selvanayagam, M. (2010). "Biofouling and its control in seawater cooled power plant cooling water system - a review," in Nuclear Power, ed P. Tsvetkov (Rijeka: InTech), 191-242.

Schultz, M. P., Bendick, J. A., Holm, E. R., and Hertel, W. M. (2011). Economic impact of biofouling on a naval surface ship. Biofouling 27, 87-98. doi: 10.1080/08927014.2010.542809

Siewert, T. A. (2004). Coatings for Corrosion Protection: Offshore Oil and Gas Operation Facilities, Marine Pipeline and Ship Structures. Biloxi, MS: NIST.

Skovhus, T. L., Enning, D., and Lee, J. S. (2017). Microbiologically Influenced Corrosion in the Upstream Oil and Gas Industry. Boca Raton, FL: CRC Press.

Smith, D. C., Simon, M., Alldredge, A. L., and Azam, F. (1992). Intense hydrolytic enzyme activity on marine aggregates and implications for rapid particle dissolution. Nature 359:139. doi: 10.1038/359139a0

Smith, D. C., Steward, G. F., Long, R. A., and Azam, F. (1995). Bacterial mediation of carbon fluxes during a diatom bloom in a mesocosm. Deep Sea Res. II Top Stud. Oceanogr. 42, 75-97. doi: 10.1016/0967-0645(95)00005-B

Steinberg, N., and Kolodkin-Gal, I. (2015). The matrix reloaded: how sensing the extracellular matrix synchronizes bacterial communities. J. Bacteriol. 197, 2092-2103. doi: 10.1128/JB.02516-14

Stocker, R. (2012). Marine microbes see a sea of gradients. Science 338, 628-633. doi: 10.1126/science.1208929

Turkiewicz, A., Brzeszcz, J., and Kapusta, P. (2013). The application of biocides in the oil and gas industry. Nafta-Gaz 2, 103-111.

Tyagi, M., da Fonseca, M. M., and de Carvalho, C. C. C. R. (2011). Bioaugmentation and biostimulation strategies to improve the effectiveness of bioremediation processes. Biodegradation 22, 231-241. doi: 10.1007/s10532-010-9394-4 van der Merwe, P., Lannuzel, D., Nichols, C. A. M., Meiners, K., Heil, P., Norman, L., et al. (2009). Biogeochemical observations during the winter-spring transition in East Antarctic sea ice: evidence of iron and exopolysaccharide controls. Mar. Chem. 115, 163-175. doi: 10.1016/j.marchem.2009. 08.001

Vigneron, A., Alsop, E. B., Chambers, B., Lomans, B. P., Head, I. M., and Tsesmetzis, N. (2016). Complementary microorganisms in highly corrosive biofilms from an offshore oil production facility. Appl. Environ. Microbiol. 82, 2545-2554. doi: 10.1128/AEM.03842-15

von Ammon, U., Wood, S. A., Laroche, O., Zaiko, A., Tait, L., Lavery, S., et al. (2018). The impact of artificial surfaces on marine bacterial and eukaryotic biofouling assemblages: a high-throughput sequencing analysis. Mar. Environ. Res. 133, 57-66. doi: 10.1016/j.marenvres.2017. 12.003

Wahl, M. (1989). Marine epibiosis. I. Fouling and antifouling: some basic aspects. Mar. Ecol. Prog. Ser. 58, 175-189. doi: 10.3354/meps058175

Wang, H., Teng, F., Yang, X., Guo, X., Tu, J., Zhang, C., et al. (2017). Preventing microbial biofilms on catheter tubes using ultrasonic guided waves. Sci. Rep. 7:616. doi: 10.1038/s41598-017-00705-8

Westall, F., de Wit, M. J., Dann, J., van der Gaast, S., de Ronde, C. E. J., and Gerneke, D. (2001). Early Archean fossil bacteria and biofilms in hydrothermally-influenced sediments from the Barberton greenstone belt, South Africa. Precambrian Res. 106, 93-116. doi: 10.1016/S0301-9268(00)00127-3

Wetzel, R. G. (ed.). (2001). "Land - Water interfaces: attached microorganisms, littoral algae, and zooplankton,” in Limnology, 3rd Edn. (San Diego, CA: Academic Press), 577-623. doi: 10.1016/B978-0-08-057439-4.50023-X

Whitman, W. B., Coleman, D. C., and Wiebe, W. J. (1998). Prokaryotes: the unseen majority. Proc. Natl. Acad. Sci. U.S.A. 95, 6578-6583. doi: $10.1073 /$ pnas.95.12.6578

Williamson, C. H., Jain, L. A., Mishra, B., Olson, D. L., and Spear, J. R. (2015). Microbially influenced corrosion communities associated with fuelgrade ethanol environments. Appl. Microbiol. Biotechnol. 99, 6945-6957. doi: 10.1007/s00253-015-6729-4

Yoshii, T., Ueda, K., and Uchino, K. (1972). Anti-fouling system for ship hull by electrolysis of sea water. Corros. Eng. Dig. 21, 523-529. doi: 10.3323/jcorr1954.21.11_523

Yuan, S. J., Pehkonen, S. O., Ting, Y. P., Kang, E. T., and Neoh, K. G. (2008). Corrosion behavior of type 304 stainless steel in a simulated seawater-based medium in the presence and absence of aerobic Pseudomonas NCIMB 2021 bacteria. Ind. Eng. Chem. Res. 47, 3008-3020. doi: 10.1021/ie071536x

Zhang, M., Jiang, S., Tanuwidjaja, D., Voutchkov, N., Hoek, E. M., and Cai, B. (2011). Composition and variability of biofouling organisms in seawater reverse osmosis desalination plants. Appl. Environ. Microbiol. 77, 4390-4398. doi: 10.1128/AEM.00122-11

Zips, A., Schaule, G., and Flemming, H. C. (1990). Ultrasound as a means of detaching biofilms. Biofouling 2, 323-333. doi: 10.1080/089270190093 78154

ZoBell, C., and Anderson, D. Q. (1936). Observations on the multiplication of bacteria in different volumes of stored sea water and in the influence of oxygen tension and solid surfaces. Biol. Bull. 71, 324-342. doi: 10.2307/1537438

Zobell, C. E. (1943). The effect of solid surfaces upon bacterial activity. J. Bacteriol. $46,39-56$.

Zuo, R. (2007). Biofilms: strategies for metal corrosion inhibition employing microorganisms. Appl. Microbiol. Biotechnol. 76, 1245-1253. doi: 10.1007/s00253-007-1130-6

Conflict of Interest Statement: The author declares that the research was conducted in the absence of any commercial or financial relationships that could be construed as a potential conflict of interest.

Copyright (c) 2018 de Carvalho. This is an open-access article distributed under the terms of the Creative Commons Attribution License (CC BY). The use, distribution or reproduction in other forums is permitted, provided the original author(s) and the copyright owner are credited and that the original publication in this journal is cited, in accordance with accepted academic practice. No use, distribution or reproduction is permitted which does not comply with these terms. 